\title{
CSDP MISSIONS AND OPERATIONS AS INSTRUMENTS OF EU CRISIS MANAGEMENT - THEIR ESSENCE, ROLE AND DETERMINANTS
}

\author{
Kamil ZAJĄCZKOWSKI, PhD \\ Centre for Europe, University of Warsaw, Poland \\ k.zajaczkowski@uw.edu.pl
}

\begin{abstract}
The aim of this article is to highlight the essence, the meaning and the role of EU civilian missions and military operations conducted under the umbrella of the Common Security and Defence Policy (CSDP). The first two parts constitute an introduction which presents the institutional framework, scope and mandate of EU missions/operations as well as their nature. The subsequent parts constitute an attempt to answer the question of what distinguishes EU missions/operations and what their specificity is. In this context, the CSDP crisis management model is presented along with the significance of operations in building the EU's international identity and in strengthening the political dimension of European integration, especially in relation to security and defence policy. The main weaknesses and shortcomings of CSDP missions/operations have also been characterized. Thusly, eleven such weaknesses have been identified which, to a large extent, determine the shape, scope and nature of CSDP missions and operations carried out by the European Union.
\end{abstract}

Keywords: European Union, Common Security and Defence Policy (CSDP), EU missions/operations, civilian and military activities under the CSDP, crisis management.

Introduction and methodological aspects - the assumptions, subject, objective, questions, and research methods

Military operations and civilian missions under the European Security and Defence Policy and, subsequently, the Common Security and Defence Policy (CSDP) have been organised since $2003^{1}$ and institutional and decision-making mechanisms have been established for such missions and operations.

\footnotetext{
${ }^{1}$ In this article, civilian expeditionary activities of the CSDP are referred to as "missions". Military activities are referred to as "operations" (including EU military training missions, i.e. non-executive military missions described as the European Union Training Mission). The terminology is in line with EU practice and is also applied in EU institutions, including the European External Action Service. At the same time it has to be pointed out that in the Treaty on the European Union - in the Lisbon Treaty version - both civilian and military activities under the CSDP are referred to as "missions".
} 
My fundamental assumption is that CSDP missions and operations constitute a vital element in building the EU's international identity. The EU's activity in this regard should refer to the entire sphere of the EU's foreign relations. The operational activities of the European Union (the CSDP 's missions/operations) are to define its position as an effective actor in international relations and to play a stabilising role in international relations.

The choice of such a research topic as a case study of EU international activity is justified and intentional. EU missions and operations are a manifestation of the political sphere of European integration development as well as an expression of efforts to strengthen this component in the EU, and, in particular, the facets related to security and defence policy. With the operational criterion in mind, EU missions and operations are one of the EU's crisis management instruments and, in a broader perspective, are part of the EU's comprehensive approach executed in its relations with the outer world. They are also somewhat a reflection of the state of European integration in the political dimension. On the one hand, the objective and subjective scope of EU missions and operations is constantly expanding, which denotes the evolution of the CSDP. On the other hand, they are of limited scale and scope, which proves the difficulties posed by the development of the CSDP and, more broadly, by political European integration. Some researchers describe them as unchallenging or even unambitious whilst citing "their inability fully to resolve problems on the ground" (Menon, 2009, p. 230).

The research topic is intended to highlight the specificity and importance of CSDP missions and operations in the sphere of EU international activities. This analysis will allow the drawing of conclusions with regards to the determinants, premises as well as potential challenges related to the execution of CSDP missions and operations. The main objective of the research is, therefore, an attempt to comprehend the basic issues and concepts vital from the vantage point of the research question, and an attempt to reconstruct and, subsequently, examine the phenomenon of CSDP missions and operations, in particular:

- institutional and legal foundations and crisis management mechanisms within the CSDP, as well as the ways of formulating goals and shaping the principles and norms in this regard (who formulates them, what they encompass and what constitutes their normative and theoretical basis); 
- operational activities of the CSDP, which create a specific model of conduct of the EU in this regard,

- trends, phenomena and processes related to the development of CSDP missions and operations.

- As a consequence of choosing such a research question and such objectives there is a need to obtain answers to the following research questions:

- what is the institutional and operational basis of CSDP missions and operations,

- what is the objective scope and the dynamics of the evolution of changes concerning CSDP missions and operations,

- what distinguishes CSDP missions/operations, what is their specificity,

- what are the characteristics of the crisis management model under the CSDP and what are its features,

- what is the role of the EU as an actor in crisis management and conflict prevention in international relations,

- to what extent are the operational activities of the CSDP compatible with other EU activities,

- what are the determinants and premises affecting the coherence of CDSP operational activities.

Bearing the abovementioned questions in mind, I have formulated the following research hypothesis which is based on the assumption that CSDP missions and operations executed by the EU contribute to enhancing the EU's role as an actor in crisis management and conflict prevention. At the same time, their risk factor is low. They are carried out on a small or medium scale and they constitute one of a few - but not the most important - instruments (measures) of the EU's influence on the international environment. CSDP missions and operations should be perceived as complementary to other EU external activities in the context of the EU's comprehensive approach principle in the EU's international strategy, which is manifested by the fact that they encompass elements of development assistance, economic cooperation and CFSP, interrelated and coordinated with one other. The EU is therefore not a typical actor/subject in the field of international security. 
Various research methods were required to write the paper. With the application of the factor method, I identified the factors and trends shaping the CSDP, including its missions and operations. The systemic method, however, was applied in the context of analysing the claims referring to the institutional and processual character of the EU's external relations, as well as showing these relations as a specific model of EU activity in the world. Due to the specific nature of my research topic, I also applied the legal and institutional analysis. To compile and evaluate the effectiveness of the CFSP (and CSDP), I used the quantitative and qualitative analysis. And finally, in my attempt to outline the direction in which the EU's foreign and security policy would develop, I implemented the scenario method.

The main objective of this article is to educate and broaden one's knowledge on the essence and importance of CSDP crisis management missions and operations, but also to develop research in this area and to present it in the context of general EU activity in the world.

\section{The scope and mandate of CSDP missions and operations}

The ESDP was to provide Member States with a flexible tool so that they would be readily equipped to respond to crises which threaten, directly or indirectly, their security. It should be noted that from the very beginning of the ESDP's existence (and subsequently the CSDP), two important restrictions have been taken into consideration with regards to that policy which, to this day, determine the essence and significance of crisis management operations.

Firstly, CSDP missions/operations are only to address broadly defined crisis management issues and cannot exceed that scope. According to Nicole Gnesotto, the EU's definition of the term "defence" is solely crisis management outside the EU, not a policy of defending its own territories and citizens (Gnesotto, 2012, p. 28). EU missions and operations deployed in crisis areas and those where the EU can use civilian and military means (so-called Petersberg tasks) include: joint disarmament operations, humanitarian and rescue missions, military advice and assistance missions, conflict prevention and peace-keeping missions, combat forces in crisis management including missions to restore peace and stabilize post-conflict situations. All those missions/operations can contribute to the war against terrorism by, inter alia, supporting third countries in combating terrorism in their territories (Article 43(1) TEU in the Lisbon Treaty version). 
Secondly, the development of the EU's ability to act in the realm of its security and defence policy cannot undermine NATO's position as a fundamental pillar of European security. The ESDP, and currently the CSDP, is not an alternative to NATO. Indeed, it is quite the opposite. The CSDP is to contribute to the increase of the EU's international activity and at the same time it is treated, at best, as an instrument for the Common Foreign and Security Policy's (CFSP) implementation and not as a system of joint defence. Therefore, it does not incorporate the formation of the so-called territorial defence which remains in the hands of NATO. As Dariusz Milczarek notes "this restrictive interpretation is supported by the decisions made at the summits in Köln and Helsinki (respectively in June 1999 and December 1999 - author's note), under which the tasks of the CSDP were limited to executing the "Petersberg tasks" (Milczarek, 2013, p. 484). During those summits, it was reiterated that NATO would remain the foundation for the collective defence of its members and that it would continue to play an important role in resolving crises. It was also stated that the development of the EU's defence policy would take place without prejudice to the obligations arising from Article 5 of the Washington Treaty and Article V of the Brussels Treaty. It was also declared that missions/operations conducted by the EU should not interfere with nor replicate NATO operations. Pursuant to Article 42(2)(2) of the TEU, in the wording of the Lisbon Treaty, the CSDP respects the obligations arising from the North Atlantic Treaty for member states, which believe that their joint defence is carried out within NATO.

The terms "crisis management" and "peace-restoring missions" are not specified in the treaty and may therefore refer to military operations. Those, in turn, are not tantamount to armed interventions. EU military operations may not exceed the scope of Petersberg tasks; EU military operations' goal is to maintain or enforce peace through sheer presence, the prevention of conflicts and the strengthening of international security (Przybylska-Maszner, 2009, p. 11).

In the TEU in the Lisbon Treaty version, the institutional mechanism of the CSDP was based on the Council as an intergovernmental institution. It is the Council which, at the request of the High Representative of the Union for Foreign Affairs \& Security Policy or at the initiative of a Member State, unanimously adopts decisions on undertaking an missions/operation (Article 42(4) of the TEU in the Lisbon Treaty version), specifying their purpose and scope as well as general conditions for their execution (Article 43(2) of the TEU in the Lisbon Treaty version) (Consolidated versions of the Treaty ..., 2012). Missions/operations involve Member States which express their consent (the Council's decision to execute an mission/operation is not tantamount to 
the fact that the country will be willing to allocate its forces to that mission/operation) as well as third countries - non-member states, which provide adequate military or financial contribution. No UN mandate is required to commence a CSDP mission/operation, although every mission/operation undertaken has been mandated thus far. It is also customary for EU missions/operations to be undertaken with the consent of the countries interested, except when the country, on whose territory the mission/operation is to be executed, is in crisis and has no effective executive authority (which has not happened yet - as of May 1st, 2020) (Przybylska-Maszner, 2009, p. 16).

The scope and mandate of an individual EU civilian and military mission/operation "are the result of a well-defined process that combines a political assessment of the situation, various planning steps, and decision-making procedures"(Missiroli (ed.), 2016, p 52). The systemic structure of the CSDP is based on the relationships established between the Union and the Member States by the Treaties which obligate them to support the Union in fulfilling its primary goal in that respect, i.e. crisis management in the international environment (Góralski, 2009, p. 82). This relationship is complemented by the CSDP decision-making system. The High Representative of the Union for Foreign Affairs \& Security Policy, under the direction of the Council and in close and constant consultation with the Political and Security Committee (PSC), supervises the coordination of the civilian and military aspects of missions/operations (Article 43(2) TEU in the Lisbon Treaty version). The organizational structure of an mission/operation is based on a political and military mechanism consisting, on one hand, of the Political and Security Committee - the PSC and its subordinate bodies (within the EU Council) ${ }^{2}$ and, on the other, of the European Union External Action (which reports to the High Representative of the Union for Foreign Affairs \& Security Policy) and the institutions operating within ${ }^{3}$.

Neither the Treaties nor the conclusions of the European Council impose any geographical restrictions on activities executed with its consent. However, regarding the geographical criterion, all EU military operations and civilian missions to date have mostly focused on two regions: the

\footnotetext{
${ }^{2}$ The Political and Security Committee - the PSC supervises the following: the European Union Military Committee - EUMC; the Politico-Military Group - PMG; the Committee for Civilian Aspects of Crisis Management - CIVCOM.

${ }^{3}$ European Union External Action incorporates, besides geographical departments and departments dealing with supranational issues, the following institutions responsible for crisis operation execution: The Crisis Management and Planning Directorate - CMPD; European Union Military Staff - EUMS; The European Union Intelligence Analysis Centre - INTCEN; Civilian Planning and Conduct Capability, CPCC.
} 
Balkans and, mainly, Africa. So far the European Union has executed (or is still running) a total of 36 missions and operations, half of which ( 9 military and 9 civilian) have been conducted or are still in progress in Sub-Saharan Africa ${ }^{4}$ (In December 2019 the Council established new a European Union CSDP civilian advisory mission in the Central African Republic - EUAM RCA. Full operational capacity of EUAM RCA was reached in June 2020).

\section{Types of CSDP missions and operations}

Due to the subject criterion, civilian missions and military operations should be distinguished under the CSDP; they have "the same goal but are run separately and differ significantly in some of their key characteristics"(Missiroli (ed.), 2016, p. 61).

Civilian crisis management missions are an important platform for the EU's external activities. As Andrzej Ciupiński notes, "there are a number of uncertainties, or at least ambiguities related to the terminology of such operations" (Ciupiński, Warsaw 2008, p. 280). The most succinct definition defines them as "interventions with a non-military personnel involvement in a violent or non-violent crisis to prevent its further escalation thus contributing to its resolution" (Ciupiński, Warsaw 2008, p. 280). Another definition describes a mission as one "...which involves the use of civilian assets to prevent a crisis, to respond to an ongoing crisis, to tackle the consequences of a crisis or to address the causes of instability" (Tardy, 2017, p. 9). "Another characteristic of EU civilian crisis management is that it is partly defined by default, i.e. by what it is not, in opposition to military crisis management (...): it brings together all crisis management activities (including police-related) that are of a non-military nature. Such opposition is specific to the EU as one of the only international security organizations that tries to make a clear distinction between the two types of activities (although the distinction can get blurred, for example when police activities are performed by Gendarmerie-type forces, or when CSDP civilian missions are manned predominantly or exclusively by military officers)" (Tardy, 2017, p. 10). Some researchers, however, believe that "the multidimensional nature of the EU makes it inherently better suited for civilian work when compared with NATO, whose mission has historically been military in nature. Others argue that, even if NATO were able to undertake civilian work in crisis

\footnotetext{
${ }^{4}$ See: https://eeas.europa.eu/topics/military-and-civilian-missions-and-operations/430/military-and-civilian-missions-andoperations_en [accesses on 23 July 2020].
} 
zones, the EU would still have a comparative advantage, given that it will never develop military capabilities on par with NATO "(Chivvis, 2010, p. 1). Thus, it should be stated that civilian missions constitute "an original EU institution", unparalleled to any international organization. The following types of civilian missions can be distinguished as parts of the CSDP: the Police Mission, the Capacity building Mission, the Border Assistance Mission (in other words: border missions or training and control missions), missions to strengthen the rule of law (in other words: the Rule of Law Mission), security sector reform missions, the Monitoring Mission (in other words: observation missions), and mixed civil-military missions.

Military operations under the CSDP constitute an important element of the European Union's external activity to ensure peace and stability. Unlike civilian missions though, military operations are far more expensive and incorporate a greater number of people, require extended preparation and comprise soldiers assigned by Member States involved in those operations.

Currently (as of May 1st, 2020) the EU is running 11 civilian missions (including a mission established in December 2019 - a civilian advisory mission in the Central African Republic EUAM RCA). It is also running 6 military operations. A sum total of 5,000 people are involved in all missions and operations.

\section{The EU crisis management model under the CSDP}

By running civilian and military crisis management missions/operations, the European Union shapes a specific model of conduct in that respect. It is not permanent; it evolves with subsequent institutional and legal changes within the EU itself and within the framework of the Treaties. Each of the missions and operations under the CSDP is determined by various conditions and premises. However, some common elements can be distinguished.

\section{a) The EU as one of many structures involved in stabilizing a situation}

The CSDP missions and operations conducted by the EU have been "organized in countries where the EU has been only one of many structures involved in stabilizing the situation" (Starzyk-Sulejewska, 2009, p. 124). As noted in one of the works: "CSDP missions/operations are

\footnotetext{
${ }^{5}$ See: https://eeas.europa.eu/topics/military-and-civilian-missions-and-operations/430/military-and-civilian-missions-andoperations_en [accessed on 23 March 2020].
} 
deployed in an international environment characterized by the presence of a multitude of other actors involved in crisis management at different legal, political and operational levels" (Missiroli (ed.), 2016, p. 47).

\section{b) Small and medium scale CSDP s operations and missions}

Such missions/operations are run on a small or medium scale. Their role and significance should not be overestimated. The EU commences zero missions/operations, especially independent military ones from square one, without the UN's or other regional structures' involvement due to its current state of military development and civilian operational capabilities (Musioł, 2012/2013, p. 343).

c) A clear and transparent CSDP mission/operation mandate in accordance with the principles of international law

EU missions and operations executed under the CSDP are based on a clear and transparent mandate "...derived from recognized principles of international law. Every EU mission/operation has at least the official support of the UN Security Council or a direct mandate of the Security Council" (Starzyk-Sulejewska, 2009, p. 123). Ryszard Zięba notes that the EU skilfully sidesteps situations where involvement in an ongoing conflict would make it look as if it was trying to pursue its own interests or play the role of "world policeman" (Zięba, 2003, pp. 210-211).

\section{d) The United Nations - a strategic partner of the EU}

The EU points to the UN's leading role in shaping international peace and securityand highlights the requirement to coordinate any civilian and military crisis management activities with the UN. As far as relations with the UN are concerned, the European Union refers to the principle of "effective multilateralism" (Hoffmann, 2010, p. 106). CSDP missions/operations are an example of the implementation of this principle which became the cornerstone for the Joint Declaration on EU-UN cooperation in Crisis Management, signed by the EU and the UN in 
September $2003^{6}$. The EU was the first organization to sign a cooperation agreement with the $\mathrm{UN}^{7}$. In 2007 the Declaration was updated and the mutual obligations were extended (Joint Statement on UN-EU Cooperation in Crisis Management). Collaborative efforts between the two institutions have been formalized through successive Action Plans. In 2012 the EU issued its own 'Action Plan on CSDP support to UN peacekeeping'which consequently led to a 'UN-EU Strategic Partnership on Peacekeeping and Crisis Management' covering the period 2015-2018 ${ }^{8}$. Between 2013 and 2015 the EU and the UN operated in parallel in Mali, the Central African Republic (CAR), RD Congo, Somalia, Kosovo and the Middle East. At the same time, we have to point to the challenges related to the execution of the partnership with regards to crisis management between the parties. In addition to those addressing such issues as joint strategic planning, division of labour, joint reviews and coordination of exit strategies, one of the most important issues, according to the UN, is the insufficient direct involvement of the EU (regarding the number of soldiers) in UN missions ${ }^{9}$. One of the reasons for this is the development of the EU's independent operational capabilities under the CSDP and the desire to primarily use that instrument at the expense of the UN missions' involvement (for political and geostrategic reasons, which will be presented here in below).

\section{e) International regional organizations}

Besides UN forces, international regional organizations (and their military missions) underpin crisis management activitiesand EU missions/operations only offer support to them. Such

\footnotetext{
${ }^{6}$ The parties agreed to establish a joint consultative mechanism at a working level to enhance coordination and compatibility in four fundamental areas including: planning, training, communication and best practices (Starzyk-Sulejewska, 2015, p. 279). The UN-EU Steering Committee was also appointed, bringing together representatives of the two organizations twice a year to discuss issues of common interest. "The UNSC meets annually with the EU's Political and Security Committee, and holds regular meetings on UN-EU cooperation with the UN Secretary- General and the HR/VP. Liaison Offices were also set up: currently the EU Delegation to the UN ensures this function, and in 2011 a UN Liaison Office for Peace and Security (UNLOPS) representing the three UN Departments responsible for peace operations and political missions (Department for Peacekeeping Operations, DPKO; for Political Affairs, DPA; and for Field Support, DFS) was set up in Brussels".(EU-UN cooperation..., 2015, p. 6), http://www.europarl.europa.eu/RegData/etudes/BRIE/2015/572783/EPRS_BRI(2015)572783_EN.pdf (accessed on: 28 March 2020).

7، The Joint Declaration came in the context of the first instances of cooperation on the ground in 2003, namely in Bosnia and Herzegovina where the EU Police Mission (the EU's first CSDP mission) took over the policing mandate from the UN International Police Task Force, and in RD Congo where the EU deployed one of its first military operations (Artemis)". (EU-UN cooperation ..., 2015,p. 6).

${ }^{8}$ In the crisis management domain, the EU Global Strategy of 2016 states that the CSDP could "assist further and complement UN peacekeeping through bridging, stabilisation or other operations". (Missiroli (ed.), 2016, p. 57).

${ }^{9}$ The uniformed personnel contribution of EU Member States is around 5\% of total UN military and police personnel (in the mid-1990s it was around 30\% and in 2010 around 8.3\%). (EU-UN cooperation..., 2015, p.11).
} 
a stance results from (the objective weaknesses of the EU aside) the EU's and some Member States' negative experiences. In the 1990s, a spotlight was shone on the helplessness of Western countries in the face of wars and conflicts, especially on the African continent. According to EU representatives, international regional organizations with their peacekeeping forces are vital in conflict prevention at the regional level and their activities should be tantamount to those of UN peacekeeping forces. At the same time, the EU supports regional security structures and institutions financially, politically and logistically (in Africa: the African Union, as well as subregional organizations, including ECOWAS, IGAD, SADC). EU military operations and civilian missions are of strictly limited mandate and nature adapted to the activities of the UN and regional organizations.

\section{f) An integrated and comprehensive approach to crisis management}

An integrated and comprehensive approach to crisis management is currently one of the CSDP's vital leanings which are stipulated by a number of documents including the European Security Strategy of 2003 and the EU Global Strategy of 2016. They are examined in three dimensions: security-development nexus, civilian-military synergies, and internal-external security nexus.

Firstly, CSDP missions and operations are one of many elements of EU crisis management. Conflicts and disputes cannot be resolved by force alone and, to this end, the EU utilises all instruments at its disposal which enables it to bring to bear long-term and very much needed changes in conflict areas without limiting itself to just temporary resolutions. N. Gnesotto points out that "The EU's intervention ensures that a whole range of non-military crisis management measures can be applied to complement its military activity" (Przybylska-Maszner, 2014; Barburska, 2020). In the European Consensus on Development from 2006, one can read that: 'without peace and security, development and poverty eradication are not possible, and without development and poverty eradication no sustainable peace will occur (Joint statement by the Council ..., 2006, p. 7, point 40).

Secondly, an integrated and comprehensive EU approach is also perceived through combining military and civilian crisis management capabilities. In crisis situations, "...there is no military or civilian activity only. Military operations always incorporate civilian elements, and civilian missions incorporate military elements" (Musioł, 2012, p. 79). These issues have been 
adequately described by Snowy Lintern: "Notwithstanding the complicated development process, military capabilities could be used in civilian missions, and civilian capabilities could be used for military operations. Examples include: civilian or military aircraft/ships/vehicles for deployment or intra-theatre transport, including the potential use of centralized 'EU' equipment from the warehouse; civilian or military satellite/aircraft/drones for air surveillance (such as the Luxembourg civil patrol aircraft provided for surveillance in Operation Atalanta); civilian or military personnel for force protection (i.e. civilian personnel for EUTM, or military teams to protect civilian ships); civilian or military personnel for medical tasks (i.e. medical support or medical evacuation)" (Lintern, 2017, p. 36). What is more, there have been cases wherein military operations conducted by the EU in the first phase of said operations have subsequently been replaced with civilian missions. One such situation, for example, took place in the Democratic Republic of Congo. Operation Artemis, as it was known, was later replaced by three successive civilian missions: Eupol Kinshasa, Eusec DRC and Eufor DR Congo. In other cases, police (civilian) missions are supported by military operations. As Joanna Starzyk-Sulejewska notes, it "...proves the comprehensive and integrated nature of the undertaken missions/operations in almost every case, even though in individual cases they are clearly defined as civilian missions or military operations" (Starzyk-Sulejewska, 2009, p. 123). Snowy Lintern concludes: "The EU military is not like NATO, or even 'NATO-like', it is a small but important component of the EU's suite of tools to deliver external action. This, by definition, means that civilian-military synergies, linking an important military role with a much larger civilian response, are only likely to grow, in part as a response to the long-term evolutions of civilian crisis management" (Lintern, 2017, p. 40).

The third dimension of the integrated and comprehensive approach in crisis management refers to an even closer correlation between external action and the internal area of freedom, security and justice. The EU Global Strategy (EUGS) states that "Internal and external security are ever more intertwined: our security at home entails a parallel interest in peace in our neighbourhood and surrounding regions. It implies a broader interest in preventing conflict, promoting human security, addressing the root causes of instability and working towards a safer world "(EU global strategy. Shared Vision ..., 2016, p. 14). In the Global Strategy it is highlighted that "...the external cannot be separated from the internal. In fact, internal policies often deal only with the consequences of external Dynamics "(EU global strategy. Shared Vision ..., 2016, p. 17). 


\section{The EU as an actor in the field of crisis management and conflict prevention in international relations}

Despite a number of CSDP weaknesses (resulting from the structure, nature, and essence of the EU but also having a financial, operational and institutional background - see: the next chapter of this article). "CSDP missions/operations are the most visible manifestations of EU activity in the international security domain (especially in fragile states), and have been the most tangible examples of the progress of the CSDP as well as of EU's security actorness" (Tardy, 2015, p. 17; Bassi, 2016). At the same time, as abovementioned, they constitute elements of a comprehensive and integrated approach of the EU to external conflicts and crisis situations, which are characterized by combining political, economic and development activities with military ones. According to Anand Menon: "The Union is unique among international organizations in its capacity to contribute to all three aspects of post-conflict stabilization: security (military and policing), economic and humanitarian, and political and institutional" (Menon, 2009, p. 228). As part of the Treaty of Lisbon, the European Union acquired "... a multidimensional set of instruments (political, economic, security), in order to promote a more comprehensive approach" (Bassi, 2016, p. 5). As Thierry Tardy rightly notes: "There is a theoretical match between the multidimensionality of crises and the multidimensionality of EU instruments that de facto makes the EU a prominent actor of crisis management"(Tardy, 2015, p. 41).

Therefore, military operations and civilian missions as well as preventive diplomacy activities are part of the EU's global strategy. These kind of operations "...became an important tool at the EU's disposal to deal with instability in a broader area" (Galantino, Freire, 2015, p. 5). "The diversity of civilian and military CSDP missions conducted since 2003 underpinning the EU's foreign policy with concrete interventions and contributing to make it a credible actor in the field of crisis management and conflict prevention" (Garcia-Perez, Glume, 2015, p. 168).

The construction of EU civilian and military operational capabilities in crisis management is also part of, as Luis Simón puts it, "the EU's foreign political ambitions", which were expressed in numerous EU strategic documents and treaties. These are: "Effective participation in managing the global system and contributing to international security as well as promoting stability and good governance in more distant European countries" (L. Simón, 2011, p. 11). 
The EU's operational capabilities (military and civilian) are not only aimed at laying the foundations and establishing instruments for EU intervention in the world but, vitally, they are intended to authenticate the feasibility of conducting it. Hence, the EU's operational capacity under the CSDP is a message sent globally to strengthen the EU's position on the international stage. It also allows the Union to gain greater independence in conducting military operations and civil missions (in neighbouring countries or where the USA shows no interest in conducting such operations) (Rynning, 2011, p. 26; Pape, p. 10, 17).

Defensive realists perceive EU missions and operations in two ways. Firstly, they are seen as an expression of assuming greater responsibility for security by the Europeans, which is manifested by CSDP missions/operations conducted without the support of the US and - more broadly - NATO and, secondly, as a form of strengthening transatlantic relations ("...through cooperation under the CSDP, European countries maximize their power and influence and, at the same time, become a better partner for the US" (Czaputowicz, 2013, p. 13)) and NATO.

Catherine Gegout, however, referring to the views of structural realists, states that EU missions and operations are somehow aimed at "soft balancing" the US (Gegout, 2009, pp. 408409). She portrays the European Union as an independent actor in terms of security, especially with respect to the United States. C. Gegout provides the Artemis military operation in the Democratic Republic of Congo of 2003 as an example. According to the researcher, it was an opportunity to manifest the EU's unity in the context of the divergent positions of Member States regarding the intervention in Iraq, and to show that the EU is capable of conducting independent military operations (without US and NATO assistance) on the international stage (Gegout, 2009, p. 408, 411; Gegout, 2005, p. 429; Pieper, Lak, 2019; Mazur, 2020).

Due to their specificity, EU civilian missions, especially those having security sector reform, police and the European Union Training Mission mandates (EUTM), are vital in shaping the normative area of stability and security in international relations. In the process of Europeanization (external) and socialization, the security systems of third countries (mission target areas) merge with EU legal and political standards regarding internal security, organization of the political system and national security as well as with the security management model. Its aim is to raise the level of security in target areas (Wojnicz, 2014, p. 272). At the same time, such activities strengthen the EU's position in those regions of the world. 
In dogmatic terms, EU military operations are contrary to the idea of a normative and civilian actor. Ian Manners claims that the use of military force creates the risk of "weakening the EU's peaceful normative power in favour of a more robust, and potentially more violent, presence" (Manners, 2006, p. 194). However, an analysis of hitherto EU military operations shows that there is no contradiction between the concept of the European Union as a normative and civil power and the tendencies to develop its military dimension. The fact that the European Union undertakes military operations is not tantamount to renouncing its role as a "civilian" and "normative" participant in international relations. Two assumptions should be made here: the fact that the EU uses military force abroad is conditioned only by normative and civilian (non-military) objectives, and that EU military operations are not combat missions, rather they are training missions in their nature. Some researchers, basing their opinion on defensive liberalism, indicate that there is premise justifying the EU's use of force in external relations, i.e. the protection of human rights and fundamental principles. Stelios Stavridis notes that promoting democratic principles globally "...might imply the need for the occasional use of military means at all" (Stavridis, 2001, p. 9; cf. Milczarek, 2003, pp. 183-194). Others, however, believe that "...normative power alone may not be persuasive enough on some occasions to influence other states and groups to alter their lawless behaviour" (Trott, 2010, p. 18; see more in: Zajączkowski, 2019, pp. 44- 48).

CSDP missions and operations express the desire to strengthen the political dimension of European integration, in particular that related to security and defence policy. However, this does not mean, as mentioned above, that military powers at the EU's disposal will become a priority in EU international operations; Member States do not consent to that (even the President of France's ideas to strengthen the CSDP garnered no support $)^{10}$. This is advocated by such arguments built around European values and the weakening of peaceful EU mission efficiency. A vital argument against undertaking such actions is also the strong position of NATO and the UN. To traverse the words of researcher Nicole Gnesotto, the real benefit of the EU as an actor in the security area arises from its comprehensive approach to ongoing conflicts and crises. Therefore, the CSDP 's missions and operations should be perceived, analysed and evaluated in that context only and not as a tool in itself to counteract wars and conflicts. CSDP missions and operations are not decisive,

${ }^{10} \mathrm{Ch}$. Hill, R. Whitmann, B. White, as early as in the 1990 s, claimed that the EU would remain a civil superpower even if it started to play a more significant role in European security since it would not be enough to transform it into a strategic actor. 
they do not determine the course of a conflict. Hence, "CSDP operations shall not be considered as the response to any kind of problem, but only as one possible option, alongside other policy alternatives such as inter alia diplomatic or humanitarian action, restrictive measures (sanctions), or abstention" (Missiroli (ed.), 2016, p. 61). The Common Security and Defence Policy does not mean transforming the EU into a security actor in a strict sense.

\section{Shortcomings and challenges}

The achievements of civilian missions and military operations have contributed to a greater "credibility" of the EU as an important player on the international stage. However, their thorough analysis shows fundamental shortcomings and challenges with regards to political and defence integration. On the one hand, proper institutional and decision-making mechanisms for conducting civilian missions and military operations have been established, but on the other, there has been no significant progress in their development. The limited character of EU missions and operations is determined by a number of the following conditions and premises:

\section{a) Intergovernmentalism for the win}

The CSDP is an organisational, intergovernmental area of the EU's functioning, "...primarily governed by the logic and conditions of inter-state negotiations determined by the will to cooperate with Member States" (Starzyk-Sulejewska, 2016, p. 460). And it seems that nothing has changed in that matter. The CSDP remains and will remain "firmly" intergovernmental (Haesebrouck, 2015, p. 15). The decision-making system in that area is based on the principle of unanimity and this requires a political agreement between Member States. At the same time, as Adrian Hyde-Price (from a neorealist perspective) states that: "Europe's great powers will continue to jealously guard their sovereign rights to pursue their own foreign and security policy priorities" (Hyde-Price, 2006, pp. 217-234; Haesebrouck, 2015, p. 15). All this means that Member States' arrangements regarding the scope and objectives of the CSDP missions/operations are based on the lowest common denominator. Some experts note that, in order to increase crisis management capabilities, it would be necessary to at least exclude the deployment of European Union Battlegroups from unanimous decision-making procedures. It seems that this idea would contribute little to the CSDP's improvement, and could lead to even greater turbulence and 
political divisions within the EU (similar to those extant while discussing the mechanisms of the mandatory relocation of refugees).

b) Different strategic cultures, interests, goals and determinants of foreign and security policies of Member States

EU Member States are not uniform in terms of strategic culture. Their attitudes towards the CSDP vary and take different forms; some belong to NATO whereas others are neutral and not involved in military activities under the CSDP. Some acknowledge the supremacy of NATO and the alliance with the US whereas some would like to be NATO independent. There are nuclear superpowers that are permanent members of the United Nations Security Council, and countries with symbolic military potential. There are large and small states, supporters of activities related solely to the defence of their own territory and those advocating interventions outside the EU. These differences constitute an obstacle in the unification of strategic cultures of European countries. The use of force is the issue that strongly divides EU countries and constitutes the greatest hurdle to the CSDP's development (Meyer, 2005, p. 545). There is no agreement between EU countries as to the motives, goals, methods, legal bases (internal and international) and approval (at internal and international level) of the use of force. Effective crisis management at the EU level is hampered by "...additional dependencies related to the nature of foreign policies of individual countries, such as there being no common external threat, geographically divergent zones of political influence, and different experiences of Member States in terms of the alliance and major geopolitical threats" (Starzyk-Sulejewska, 2016, p. 460).

Some researchers (taking into account the constructivist perspective) claim that these abovementioned differences are gradually being eradicated through socialization and the social learning of Member States. Christopher O. Meyer says that Member States have managed to reach a consensus on their use of force (which is obviously not tantamount to the eradication of differences in that respect) ${ }^{11}$. Military force is used only to fend off attacks of ethnic groups in war-affected countries thus defending European values and ideas such as human rights, democracy

\footnotetext{
${ }^{11}$ The following are conducive to achieving greater similarity of strategic cultures of EU countries and building a European strategic culture: common experiences gained during EU civilian missions and military operations, the socialization of elites in common institutions and bodies of the CSDP and the process of mediatisation of conflicts and wars. In his article, Tommi Koivula formulates a thesis that due to a number of EU military operations and involvement of soldiers from individual Member States in them, so called military ethos is created at the EU level. (Koivula, 2009, pp. 171-190).
} 
and security. Military force can be used as a last resort, should peaceful measures turn out to be unsuccessful. As a principle, its use against civilian targets should be limited. What is more, the use of force must not violate international law and must be based on the principles of multilateralism, i.e. cooperation with international organizations (primarily the UN). The fact that the principle of neutrality among European societies as well as the defence cooperation through NATO/USA is weakening, it is conducive to the use of force (Meyer, 2005, pp. 543-546; see more in: Zajączkowski, 2019, pp. 40-44).

\section{c) Battlegroups as an example of the lack of political will}

The fact that the development of the CSDP is dependent on the uniform political will of Member States constitutes a significant limitation. "A number of the CFSP's shortcomings can be attributed to the lack of political will rather than insufficient instruments or procedures" (Przybylska-Maszner, 2009, p. 32). European Union Battlegroups are an example illustrating that state of affairs $^{12}$. They have never been deployed, even though, as Andrzej Ciupiński states, there have been opportunities to do so (e.g. they could have been sent to at least two operations in Africa - in the DRC in 2006 and to the Central African Republic and Chad in 2008) (Ciupiński, Warsaw 2008, p. 213). According to Beata Przybylska-Maszner, "unless EU battlegroups become a tool for crisis management operations, it will be difficult to increase operational response capacity" (Przybylska-Maszner, 2014, p. 12).

\section{d) Only the strong ones count}

When describing the CSDP and its missions and operations, realists highlight the "..naturally strong position of a state" (Rosiński, 2014, p. 252). The CSDP is controlled by the largest of the EU countries: France, Germany and, by the end of 2019, Great Britain. Daniel Fiott points out that within the CSDP there is a significant imbalance of power in favour of those countries. "In the CSDP it is not about equality but one dependent on Europe's two or three military powers for capabilities and strategic direction"(Fiott, 2013, p. 4; Grosse, 2019). The strongest countries will agree to bear the costs of cooperation under the CSDP as long as it strengthens their

\footnotetext{
12 On 22nd October 2004 in Brussels, ministers of defence of the Member States approved the establishment of 13 battlegroups. As intended, "battlegroups" of 1500 adequately equipped soldiers should be capable of deploying in conflict areas within 15 days.
} 
influence (in line with the views of neoclassical realists). Therefore, the CSDP will only thrive if it is in the interests of those countries. The first EU military operation outside Europe under the CSDP was conducted at the behest of France (similar to the majority of CSDP missions/operations in Africa) since it was of strategic interest to Paris. Germany's increased involvement in EU missions and operations, especially since 2015 , has been related to the migration crisis, the escalation of terrorist attacks and Berlin's desire to strengthen its international positionand was also an excuse to reform the German army. Sweden had done the same, using its soldiers' involvement in EU Battlegroups to execute structural reforms within the army. The three CSDP reform initiatives adopted by the EU in 2017 are mainly in Germany's and France's interests. Their aim is also to strengthen European integration in the context of Brexit and the presidency of Donald Trump. The initiatives refer to the establishment of the Military Planning and Conduct Capability (MPCC) as part of the EU Military Staff ${ }^{13}$, the establishment of the European Defence Fund financed from the EU budget and the activation of the permanent structural cooperation mechanism (PESCO) ${ }^{14}$ back in December 2017 (Zajączkowski, 2019, pp. 11-16).

\section{e) Internal and electoral pressure}

Some researchers from the liberal school of international relations believe that the decisions of individual governments to participate in CSDP missions and operations reflect their attempts to meet voters' expectations (Pohl, van Willigen, van Vonno, 2016, p. 65; Pohl, 2014, p. 192). Governments formulate their foreign policy "...not primarily with a view to shifts in international power or norms, but with respect to what their societies want" (although the former may influence the latter) (Pohl, 2013, p. 317). This is consistent with Andrew Moravcsik's new liberalism which claims that governmental foreign policy transpires from the demands and preferences of national social groups (Moravcsik, 2008, p. 237; Moravcsik, 1997, pp. 516-524). The internal pressure exerted on governments explains the fact that EU civilian missions and military operations try to avoid risk, are time-limited and are generally not particularly ambitious. States are afraid of internal criticism and backlash for being too involved in CSDP

\footnotetext{
${ }^{13}$ MPCC will lead EU non-executive military missions, i.e. military training missions. Therefore, its role will coincide with the Civilian Planning and Conduct Capability - CPCC which has been operating since 2007.

${ }^{14}$ The instrument was implemented into acquis communautaire in the Treaty of Lisbon, but is yet to be used. PESCO is to enable closer cooperation of the Member States with regards to the CSDP provided that specified requirements are met.
} 
missions/operations, especially those of a military nature which carry the risk of human losses and entail significant expense. (According to Benjamin Pohl's logic, governments do not want to be accused of "...paying too high a price in blood or treasure"(Pohl, 2013, p. 317). Hence, Member States' involvement in missions/operations is merely symbolic. Their (personnel and financial) contribution is usually disproportionate to their possibilities. Therefore "...governments can pretend to be capable of influencing international events, without facing the risk of being accused of pointless activism"(Haesebrouck, Haesebrouck, 2015, p. 13; Pohl, 2013, p. 317). As a result, governments prefer civilian missions or non-combat military operations of the CSDP. The positions of individual Member States regarding the CFSP and CSDP are therefore "...tailored to societal preferences and priorities; that such actions would lack a credible strategic logic as the foreign policy objectives would be secondary to making domestic audiences feel good while avoiding (longer-term) risks and deflecting potential blame"(Pohl, 2014, p. 194). B. Pohl states that the development of the CSDP is determined by the fact that "EU governments are above all concerned with electoral survival" (Pohl, 2014, p. 200; see more in detail: Zajączkowski, 2019, pp. 21-26). EU civilian missions and military operations constitute some sort of emanation of that state of affairsand are the result of contradictory social expectations - the act of "doing something" by the authorities in the name of principles and values but at an acceptable cost. According to Pohl, it should be expected that EU missions and operations will continue in their current form, i.e. with a limited scope and mandate as well as limited objectives.

\section{f) Prestige, security and economy}

C. Gegout is a researcher who, in her analyses, as previously indicated, highlights the essence of realismwith specific focus on structural realism. On this particular basis she proves that EU military operations (and civilian missions) are conducted following an accurate estimation of the cost and benefit distribution on three levels; prestige, security and economy. The European Union intervenes when it is in the interest of its largest Member States, when the risk of financial and human losses is kept to a minimum, and when an operation is conducted under Security Council resolutions and is acclaimed by the international community, primarily the United States. All this means that EU interventions, including those in Africa, are few and far between and are scope-and-time limited. (Gegout, 2005, pp. 442-443; Gegout, 2009, p. 412; see also: Zajączkowski, 2019, pp. 17-20). 
g) The lack of mechanisms obligating Member States to greater contributions (financial and personnel) towards CSDP missions/operations (especially military ones)

The CSDP's institutional framework does not contribute to resolving the dilemmas of EU joint crisis management missions/operations. T. Haesebrouck, applying rational-choice institutionalism in his research, indicates two sources of the problem: the unanimity rule employed by the CSDP and the lack of formal obligation of the Member States to make (in the case of military operations) a financial and personnel contribution to CSDP missions/operations. A given country's consent to launch a CSDP mission/operation is not tantamount to direct involvement and requires no personnel deployment. However, in the case of military operations, only common costs are covered by all Member States, but they only account for approximately $10-15 \%$ of all costs ${ }^{15}$. According to Tim Haesebrouck, the lack of a centralized enforcement mechanism which would obligate states to a greater financial and personnel contribution towards missions/operations (especially military ones) results in the fact that "Member States will be tempted to try to ride cheap on the efforts of others, resulting in a pattern of small-scale and unambitious operations" (Haesebrouck, 2015, p. 14; Menon, 2011, p. 82).

\section{h) No permanent command of military operations}

According to the systemic criterion, EU military operations are conducted in accordance with the Berlin Plus agreement, i.e. with or, alternatively, without NATO funds and involvement. Since the establishment of the CSDP crisis management operation, only operation Althea in Bosnia corresponds to the Berlin Plus option. The EU mostly executes its missions/operations singlehandedly without NATO funds and involvement and when it does so it takes advantage of the temporary command of EU military operations located in one of the following five countries France, Germany, Greece, Italy and the United Kingdom. These countries obligated themselves to delegate command to operations should the need arise (such commands are established on the basis of national military centres) (Brylonek, 2014, p. 89). It is the duty of the Operational Commander

\footnotetext{
${ }^{15} \mathrm{EU}$ military operation costs are divided into two major categories: Nation Borne Costs, i.e. their own costs borne by countries delegating contingents, and common costs - borne by all countries jointly, irrespective of their participation in an operation on the basis of their GDP (Art. 41(2) TEU in the Lisbon Treaty version). In February 2004, for the benefit of military operations under CSDP, the financing mechanism ATHENA was created for handling the common costs of EU military operations (operating since 1 March 2004). The costs of civilian missions are covered by the EU budget.
} 
(OpCmr) to manage the Operation Headquarters (OHQ), i.e. the temporary command of EU military operations ${ }^{16}$. To date, no permanent command of military operations has been established (as opposed to civilian missions) ${ }^{17}$. According to Marek Brylonek "...such an approach solves the problem only partially. It has a number of disadvantages including delays in the appointment of an operational commander, the lack of a proper chain of command for military training missions and the ad hoc appointment of temporary command personnel" (Brylonek, 2014, p. 89).

\section{i) The Europeanization of bilateral operations}

Member States - those being former colonial states - often transfer their bilateral connections to the EU level due to their past which results in tighter economic and political ties with non-European areas. They are also the countries which determine the nature and scope of crisis management missions/operations in Africaand in many cases make decisions on involvement in a given region. Although a tendency towards the Europeanization of their military/political activities by individual Member States has recently become noticeable, it is not tantamount to any "communitarisation" of EU foreign policy. A great example illustrating this is the military operations undertaken by France against Mali and the Central African Republic. On the one hand, France attempts to Europeanize the conflict in Mali and the neighbouring area by deploying a mission/operation under the umbrella of the CSDP. It also highlights a number of challenges for European security related to that region. Such tactics seem beneficial for Paris because it avoids any possible accusations of attempted neo-colonialism. In addition, the recollection of a failed intervention in Rwanda (1994) is still a source of great controversy in France and defines the priorities of its policy in Africa to a great degree. On the other hand, France, as a strategic partner in the region, often pursues a policy parallel to EU activities. That certainly is not conducive to establishing an individual EU identity in international relations nor to strengthening the position of EU missions/operations in the region (Zajączkowski, 2014, p. 11).

\footnotetext{
${ }^{16}$ Such headquarters are established $a d$ hoc for a given operation and are, once an operation ceases, subsequently disbanded.

${ }^{17}$ In the case of civilian missions, the Director of the CPCC is a (permanent) civil Operational Commander (Civilian Operations Commander). The Director of the CPCC is formally Head of all operations, but each civilian mission has a Head of Mission in situ. The CPCC becomes the centre of command (Operation Headquarters).
} 
j) The multidimensional character of CSDP missions and operations: Multiple actors in a multi-level, multi-pillar and multi-location governance system

EU missions and operations are conducted not only as part of EU activities but also as part of a number of initiatives of non-EU countries, international organizations (intergovernmental and non-governmental) and foundations, among other entities. As stated in one of the analyses “...multiple actors in a multi-level, multi-pillar and multi-location governance system shows clearly that the development and implementation of security and defence policies, such as SSR programs, is more complex than one would assume from a purely formal institutional point of view and that this goes beyond the formal ESDP actors and structures " (Justaert, Keukeleire, 2010, p. 9). The multitude of (non-EU) actors involved in a given area of an EU mission/operation gives rise to a number of challenges. "The risk of deadlock in policy-making and the difficulties of effective problem-solving are the result of the multitude of actors involved, their complex and sometimes rigid formal interaction mechanisms, their semi-overlapping loyalties and the significant differences in resources, priorities and approaches "(Justaert, Keukeleire, 2010, p. 19).

\section{k) "A piecemeal" approach and not a comprehensive approach}

The effectiveness of a CSDP mission/operation in a given region is related to the coherence of EU decisions and actions regarding external relations. As already mentioned in this article, CSDP missions and operations are only one of the elements of wider EU activity in the world. And therefore they should be analysed and evaluated as such. Practice shows, however, that no sufficient coordination mechanisms for external policy have been developed. "It is not just a question of actors' will to work closely together, but also a matter of logic of action, legal prerogatives, strategies and interests within the EU security governance" (Lavallée, Völkel, 2014, p. 16). This applies not only to the coordination between economic, political and defence components of external policy, where there is an unsurprisingly clear disparity in their development (we also deal with two different understandings of their functioning). This lack of consistency also occurs within individual components. In the case of EU missions and operations, there are not only challenges related to the development-security nexus, the civil-military nexus and internal-external security nexus, but also a high level of intra-EU tensionwhich applies mainly to civilian missions. "Inter-agency rivalry is severe, and the lack of any significant agreement on a natural division of labour between the Commission and the Council is destabilizing the EU's 
efforts" (Froitzheim, Söderbaum, Taylor, 2011, p. 53). "A coherent preventive approach to conflict and crisis depends on three factors: a clear definition of objectives, capacity, and the political will to act" (Cameron, 2004, p. 10). EU missions and operations visibly lack these three factors. At the same time, developing a strategy for a given region does not solve the problem of proper correlation and, hence, a more comprehensive approach of the EU to international operations. The Sahel and the Horn of Africa are prime examples which serve as proof. In other words, the "piecemeal approach" is still dominant. The Union itself acknowledges in one of its communications that "[...] it must now make further improvements and more consistently apply the comprehensive approach as a guiding principle to EU external policy and action" (Joint Communication to the European Parliament and Council, the EU's comprehensive approach ..., 2013, p. 13).

\section{Summary}

Past operations and missions under the CSDP arouse no controversy and are characterized by their low level of risk. The fact that they resulted in zero human casualties also seems to be pertinent. They are intended for small-and-medium scale operations outside the EU. Missions and operations undertaken by the European Union undoubtedly strengthen the EU's role as an actor in crisis management and conflict prevention; they portray the EU as a vital partner in international relations. At the same time, as indicated in the article, the EU has created a specific crisis management model under the CSDP which is characterized inter alia by the following elements: the close cooperation of a mission/operation with the UN along with international regional organizations as well as an integrated and comprehensive approach to crisis management. With regards to the latter - it should be noted that EU missions/operations constitute merely one of many tools the EU has at its disposal. They are vital, but not the only and certainly not the most important means of the EU to exert influence on the international environment. The EU has created suitable institutional and decision-making mechanisms for its missions/operations. On the one hand, there has been an observable evolution of the objective and subjective dimensions - missions and operations cover new areas (recently the migration issue), and more and more countries, also from outside the EU, are involved (which does not transpire into an increased number of personnel/soldiers directly involved in them). On the other hand, one should point out the weaknesses and shortcomings that determine the shape and scope of EU missions/operations. 
These are, as abovementioned, the following: the intergovernmental nature of missions/operations and the CSDP itself, different strategic cultures, the interests, goals and conditions of foreign and security policies of Member States, the lack of unanimous political will of Member States regarding the development of CSDP, the lack of a mechanism obligating Member States to a greater contribution (in terms of finance and in the number of personnel) to missions/operations (especially military), and no permanent command of military operations.

CSDP missions and operations are a result of the state of European integration, the ambition to play a greater political and military role in the world (as evidenced by as many as 36 such missions and operations since its inception), and, at the same time, the fear of taking bolder steps towards political and defence integration (as showed by not launching EU Battlegroups). They are also the result of the ambition to become a global security actor and a visible desire to limit strictly military operations. Therefore, as emphasized in the article, the term "crisis management actor" is more suitable to describe the EU than "security actor".

The determinants, weaknesses, shortcomings as well as empirical studies of EU missions and operations indicated in this paper allow us to pinpoint several trends that perfectly illustrate the current state of development of EU missions and operations under the CSDP:

a) EU activities initially focused on military operations in both Sub-Saharan Africa and the Balkans. After a period of relatively intense activity, in particular on the African continent, during the first five years of the operationalisation of EU crisis management (between 2003 and 2008), the military component of CSDP became less prominent (Missiroli (ed.), 2016, p. 45). As of September 2020, there are no medium-to-large-scale ground military operations deployed under CSDP (operating since 2008, EU NAVFOR military operation Atalanta currently encompasses about 600 personnel). Newly established military operations/missions have an average of about 200-700 soldiers ${ }^{18}$.and these are usually military training missions. For the sake of comparison: the largest military operations are EUFOR Tchad/RCA (3700 soldiers and personnel), EUFOR RD Congo (2400 soldiers), and Operation Artemis (2000 soldiers).

\footnotetext{
18 The EUTM Mali mission currently encompasses 745 soldiers; The European Union Training Mission in Somalia (EUTM Somalia) - currently 200 soldiers, the EU Training Mission in the Central African Republic (EUTM RCA) - 181 soldiers.
} 
b) Even though military operations and civil missions have different tasks and goals, their common feature is that "...no vital national interests have been at stake" (Engberg, 2013, p. 2). During such missions/operations the risk of financial and human losses is kept to a minimum.

c) One analysis assessing the first few years of military operations stated that "the EU has chosen to intervene in conflicts that have looked more like opportunities than challenges" (Engberg, 2013, p. 3). Although this opinion may be overly suggestive, it perfectly reflects the Member States' attitude towards the conducted missions/operations.

d) The EU establishes civilian missions more eagerly. On average, CSDP civilian missions are relatively small in size, totalling approximately $120 \mathrm{EU}$ and local staff. CSDP civilian missions are relatively inexpensive and theoretically flexible (Tardy, 2017, p. 13).

e) Kacper Rękawek and Marcin Terlikowski write: "The Member States' approach to the crisis in Mali proves that they have lost interest in using CSDP structures and the political and logistical support of the entire Union to respond comprehensively to security crises. The nature of the EUTM Mali mission is consistent with the latest EU operational activity -missions such as EUTM Somalia, EUCAP Nestor and EUAVSEC in South Sudan are highly specialized, smallscale operations, and above all, they play a strictly auxiliary role in stabilizing security in the region. This trend, should it continue, will question any further expansion of the CSDP in a direction that would allow the EU to undertake more complex military or civil-military operations, which would constitute a fundamental, not auxiliary, tool for stabilizing the Union's neighbourhood" (Rękawek, Terlikowski, 2013). One should fully agree with this thesis. And it seems that this trend will not change in the foreseeable future.

f) CSDP missions/operations are "apolitical" and technical. As indicated in point e, they focus on a snippet of reality. They are not, and cannot be, the driving force in the region to which they are deployed.

g) CSDP missions and operations are neither ambitious nor sizeable. And this will remain the status quo in the future. As has been stressed several times in this article - they are, and will remain, one of the tools in the EU's external relations. Their effectiveness will, however, depend on the EU's greater coherence (i.e. greater comprehensiveness) of its activities in international relations.

h) In recent years, security has been one of a few areas in which France and Germany have managed to find common ground and have presented joint proposals in the EU forum, such as (as 
already indicated in this article): Military Planning and Conduct Capability - MPCC, European Defence Fund or the activation of the permanent structured cooperation mechanism (so-called PESCO). In the context of the analysed EU operations and missions, these proposals will translate neither into their strengthening nor an increase in the number of soldiers or civilian personnel in EU expeditionary activities. Such situations are affected, among other things, by both countries' strategically differing perceptions. Paris advocates ambitious goals in developing EU security policyand wants joint operations in the southern neighbourhood of Europe, financed to a greater extend by the EU budget. Germany, however, - a state more reserved in the use of military instruments to solve crises and conflicts in the world - perceives the development of EU cooperation in a completely different manner. For Germany, the establishment of integrated military structures (and strengthening Berlin's position within them) is more important than their possible operational use.

\section{References}

1. BARBURSKA, O. (2020) Europeizacja jako instrument polityki zagranicznej Unii Europejskiej w zakresie promocji demokracji [Europeanization As an Instrument of the EU's Foreign Policy in the Field of Promoting Democracy]. Studia Europejskie - Studies in European Affairs, no 1, pp. 9-25.

2. BASSI, A. (2016) Analysing EU normative action: the example of CSDP civilian missions. Available at: https://www.sisp.it/docs/convegno2016/188_sisp2016_relazioniinternazionali.pdf (accessed on 15 March 2020).

3. BRYLONEK, M. (2014) Bieżące trendy we wspólnej polityce bezpieczeństwa i obrony Unii Europejskiej [The Current Trends of the Common Defence and Security Policy of the European Union. A European Overview]. Przeglad Europejski, no 1, pp. 68-91.

4. CAMERON, F. (2004) The European Union and Conflict Prevention. United Nations Institute for Disarmament Research, European Policy Centre. Available at: https://www.peaceportal.org/documents/125878116/126778554/The+European+Union+a nd + Conflict + Prevention.pdf (accessed on 28 March 2020).

5. CHIVVIS, Ch.S. (2010) EU Civilian Crisis Management: The Record So Far. Santa Monica: RAND - National Defense Research Institute. 
6. CIUPIŃSKI, A. (2008) Wspólna polityka bezpieczeństwa i obrony Unii Europejskiej. Geneza, rozwój, funkcjonowanie [Common Defence and Security Policy. Its Origins, Development and Functioning]. Warsaw: Difin.

7. CONSOLIDATED VERSIONS OF THE TREATY ON EUROPEAN UNION AND THE TREATY ON THE FUNCTIONING OF THE EUROPEAN UNION, 2012/C 326/01.

8. CZAPUTOWICZ, J. (2013) Teoretyczne wyjaśnienia Europejskiej Polityki Bezpieczeństwa i Obrony [Theoretical Explanations of the European Security and Defence Policy. International Relations]. Stosunki Międzynarodowe - International Relations, vol. 48 , no 2, pp. 9-25.

9. ENGBERG, K. (2013) Ten years of EU military operations. Brief, no. 41, November, European Union Institute for Security Studies.

10. EU GLOBAL STRATEGY. SHARED VISION, COMMON ACTION: A STRONGER EUROPE. A GLOBAL STRATEGY FOR THE EUROPEAN UNION'S FOREIGN AND SECURITY POLICY, Brussels 2016.

11. EU-UN cooperation in peacekeeping and crisis management. European Parliament, November 2015, Available at: http://www.europarl.europa.eu/RegData/etudes/BRIE/2015/572783/EPRS_BRI(2015)57 2783_EN.pdf (accessed on 10 March 2020).

12. FIOTT, D. (2013) The Common Security and Defence Policy and IR Theory. Available at: https://www.e-ir.info/2013/08/20/the-common-security-and-defence-policy-and-irtheory/ (accessed on 05 March 2020).

13. FROITZHEIM M., SÖDERBAUM F., TAYLOR I. (2011) The Limits of the EU as a Peace and Security Actor in the Democratic Republic of the Congo. Africa Spectrum, vol. 46, no 3, pp. 45-70.

14. GALANTINO M.G., FREIRE M.R. (2015) Managing crises, making peace: towards a strategic EU vision for security and defence. Basingtoke: Palgrave Macmillan.

15. GARCIA-PEREZ, M., GLUME, G. (2015) Civilian CSDP missions. In: REHRI J., GLUME G.(eds.) Handbook on CSDP missions and operations. The common security and defence policy of the European Union. Vienna: Armed force printing Centre, pp. 162-168. 
16. GEGOUT, C. (2005) Causes and Consequences of the EU's Military Intervention in the Democratic Republic of Congo: A Realist Explanation. European Foreign Affairs Review, vol. 10, no 3, pp. 427-443.

17. GEGOUT, C. (2009) EU Conflict Management in Africa: The Limits of an International Actor. Ethnopolitics, vol. 8, no 3-4, pp. 403-415.

18. GNESOTTO, N. (2012) Przyszłość Europy strategicznej [The Future of a Strategic Europe]. Warsaw: The Polish Institute of International Affairs.

19. GÓRALSKI, W. (2009) Rozwój i ewolucja systemu decyzyjnego Wspólnej Polityki Zagranicznej i Bezpieczeństwa Unii Europejskiej [The Development and evolution of the decision-making system of the Common Foreign and Security Policy]. In: Parzymies, S. (ed.) Dyplomacja czy siła? Unia Europejska w stosunkach międzynarodowych [Diplomacy or Force? The European Union in International Relations]. Warsaw: Scholar Publishing House, pp. 54-84.

20. GROSSE, T.G. (2019) Dokąd zmierza polityka obronna UE? Analiza geoekonomiczna. Analiza dla Nowej Konfederacji [What is the course of the EU Defence Policy? A geoeconomic analysis. An analysis for the "Nowa Konfederacja" thinkzine]. Available at: https://nowakonfederacja.pl/wp-content/uploads/2019/03/Dok\%C4\%85d-zmierzapolityka-obronna-UE-Grosse-21.02.pdf (accessed on 20 February 2020).

21. HAESEBROUCK, T. (2015) Explaining the Pattern of CSDP-Operations: Towards a Theoretical Synthesis. Romanian Journal of European Affairs, vol. 15, no 2, pp. 5-21.

22. HOFFMANN, T. (2010) System reagowania kryzysowego w regulacjach Unii Europejskiej [The Crisis Management System in the European Union Regulations]. Zeszyty Naukowe WSOWL, no 3 (157), pp. 97-108.

23. HYDE-PRICE, A. (2006) Normative' power Europe: a realist critique. Journal of European Public Policy, vol. 13, no 2, pp. 217-234.

24. JOINT COMMUNICATION to the European Parliament and Council, the EU's comprehensive approach to external conflict and crises, the European Commission, High Representative of the European Union for Foreign Affairs and Security Policy, Brussels, 11.12.2013, JOIN(2013) 30 finale.

25. JOINT STATEMENT by the Council and the Representatives of the Governments of the Member States meeting within the Council, the European Parliament and the Commission 
on European Union Development Policy: 'The European Consensus', the European Consensus on Development, Official Journal of the European Union, (2006/C 46/01), 24.2.2006.

26. JUSTAERT, A., KEUKELEIRE, S. (2010) The EU's Security Sector Reform Policies in the Democratic Republic of Congo. In: VANHOONACKER, S., DIJKSTRA H., MAURER H. (eds.) Understanding the Role of Bureaucracy in the European Security and Defence Policy. European Integration online Papers (EIoP), Special Issue 1, vol. 14. Available at: http://eiop.or.at/eiop/texte/2010-006a.htm (accessed on 10 February 2020).

27. KOIVULA, T. (2009) Towards an EU Military Ethos. European Foreign Affairs Review, vol. 14, no 2, pp. 171-90.

28. LAVALLÉE, CH., VÖLKEL, J.C. (2014) EU security governance in the Sahel region: Implementing a multidimensional strategy in an unstable environment. Paper presented at the IPSA Annual Conference Montreal.

29. LINTERN, S. (2017) What civilian-military synergies? In: Tardy, T. (ed.) Recasting EU civilian crisis management. Paris: EU Institute for Security Studies, Report no. 31, January, pp. 35-40.

30. MANNERS, I. (2006) Normative power Europe reconsidered: beyond the crossroads. Journal of European Public Policy, vol. 13, no 2, pp. 182-199.

31. MAZUR, S.K. (2020) Doubtful Ally or Ally Full of Doubts? The Course of Transatlantic Relations under Donald Trump's Presidency. Studia Europejskie - Studies in European Affairs, no 2, pp. 9-23

32. MENON, A. (2009) Empowering paradise? The ESDP at ten. International Affairs, vol. 85, no 2, pp. 227-246.

33. MENON, A. (2011) European Defence Policy from Lisbon to Libya. Survival, vol. 53, no 3, pp. 75-90.

34. MEYER, Ch.O. (2005) Convergence Towards a European Strategic Culture? A Constructivist Framework for Explaining Changing Norms. European Journal of International Relations, vol. 11, no 4, pp. 523-549.

35. MILCZAREK, D. (2013) Foreign and Security Policy - A Challenge for the European Union. In: Milczarek D., Adamczyk A., Zajączkowski K. (eds.) Introduction to European 
Studies. A New Approach to Uniting Europe. Warsaw: Publishing Programme of Centre for Europe, University of Warsaw.

36. MILCZAREK, D. (2003) Pozycja $i$ rola Unii Europejskiej $w$ stosunkach międzynarodowych. Wybrane aspekty teoretyczne [The Position and Role of the European Union in International Relations. Selected Theoretical Aspects]. Warsaw: Centre for Europe, University of Warsaw.

37. MISSIROLI, A. (ed.) (2016) The EU and the world: players and policies post-Lisbon. A handbook. Paris: EU Institute for Security Studies.

38. MORAVCSIK, A. (1997) Taking Preferences Seriously: A Liberal Theory of International Politics. International Organization, vol. 51, no 4, pp. 513-53.

39. MORAVCSIK, A. (2008) The New Liberalism. In: Reus-Smith C., Snidal D. (eds.) The Oxford Handbook of International Relations. Oxford: Oxford University Press.

40. MUSIOE, M. (2012/2013) Operacje pokojowe i dyplomacja prewencyjna oraz ich podstawy w polityce zewnętrznej UE w XXI wieku [Peace Operations and Preventative Diplomacy and their Foundations in the External Policy of the European Union]. Rocznik Bezpieczeństwa Międzynarodowego, pp. 337-356.

41. MUSIOŁ, M. (2012) Przegląd interwencji wojskowych i cywilnych UE w Afryce na przykładzie Demokratycznej Republiki Konga [An Overview of Civilian and Military Interventions of the EU Illustrated by the Example of the Democratic Republic of Congo]. Wroctawskie Studia Politologiczne, no 13, pp. 73-91.

42. PAPE, R.A. (2005) Soft Balancing Against the United States. International Security, vol. 30, no 1, pp. 7-45.

43. PIEPER, M., LAK, M. (2019) The End of Transatlanticism? EU Security and Defence Policies and the 'Strategic Autonomy' Debate from a Historical and Contemporary Perspective. Studia Europejskie - Studies in European Affairs, no 4, pp. 23-44

44. POHL, B. (2013) The Logic Underpinning EU Crisis Management Operations. European Security, vol. 22, no 3, pp. 307-325.

45. POHL, B. (2014) To What Ends? Governmental Interests and European Union (Non-) Intervention in Chad and the Democratic Republic of Congo. Cooperation and Conflict, vol. 49, no 2, pp. 191-211. 
46. POHL, B., VAN WILLIGEN, N., VAN VONNO, C.M.C. (2016) Governmental Interest, New Liberalism and the CSDP. In: Cladi L., Locatelli A. (eds.) International Relations Theory and European Security. We thought we knew, London-New York: Routledge, pp. 65-82.

47. PRZYBYLSKA-MASZNER, B. (2014) Operacje wojskowe Unii Europejskiej w Afryce ambicje, możliwości, efekty [EU Military Operations in Africa - their ambitions, possibilities and effects]. In: PRZYBYLSKA-MASZNER, B. (ed.) Operacje wojskowe Unii Europejskiej w Afryce [European Union Military Operations in Africa]. Poznań: Publishing House of the AMU Faculty of Political Science and Journalism, pp. 9-22.

48. PRZYBYLSKA-MASZNER, B. (2009) Operacje w obszarze Europejskiej Polityki Bezpieczeństwa i Obrony - uwarunkowania i perspektywy rozwoju [European Security and Defence Policy Operations - their Determinants and Perspectives for Development]. Środkowoeuropejskie Studia Polityczne, no 1-2, pp. 7-35.

49. RĘKAWEK, K., TERLIKOWSKI M. (2013) EU CSDP in the Light of the Crisis in Mali. PISM Bulletin, 5 March 2013, no 21(997).

50. ROSIŃSKI, A. (2014) Wielowymiarowość europejskiego bezpieczeństwa i obrony założenia teoretyczne [Multidimensionality of the European Security and Defence Theoretical Concepts]. In: Czaputowicz J (ed.) Studia Europejskie. Wyzwania interdyscyplinarności [European Studies. The Challenges of Interdisciplinarity]. Warsaw: The Faculty of Journalism and Political Science of the University of Warsaw, pp. 247-268.

51. RYNNING, S. (2011) Realism and the Common Security and Defence Policy. Journal of Common Market Studies, vol. 49, no 1, pp. 23-42.

52. SIMÓN, L. (2011) Zarządzanie kryzysowe nie jest receptą na dalsze cięcia: planowanie wojskowe i wspólna polityka bezpieczeństwa i obrony po Lizbonie [Crisis Management is not a Recipe for Further Cuts: Military Planning and Common Security and Defence Policy following Lisbon]. In: Terlikowski M. (ed.) System planowania i dowodzenia misjami Unii Europejskiej. Struktura, problemy, możliwości reform [Planning and Command System of the EU Missions. Their Structure, Problems and Reform Possibilities]. Warsaw: The Polish Institute of International Affairs, pp. 7-18.

53. STARZYK-SULEJEWSKA，J. (2009) Interwencje zewnętrzne Unii Europejskiej [External Interventions of the European Union]. In: Parzymies, S. (ed.) Dyplomacja czy 
siła? Unia Europejska $w$ stosunkach międzynarodowych [Diplomacy or Force? The European Union in International Relations]. Warsaw: Scholar Publishing House, pp. 85124.

54. STARZYK-SULEJEWSKA, J. (2015) Stosunki Unii Europejskiej z Organizacją Narodów Zjednoczonych. Podstawy prawne i instytucjonalne oraz wybrane dziedziny wspótpracy [The Relations between the European Union and the United Nations. Legal and Institutional Bases. Selected Fields of Cooperation]. Warsaw: Scholar Publishing House.

55. STARZYK-SULEJEWSKA, J. (2016) Wspólna Polityka Zagraniczna i Bezpieczeństwa UE po reformie lizbońskiej - najważniejsze wyzwania [The Common Foreign and Security Policy of the EU following the Lisbon Reform - the most Important Challenges]. In: Haliżak, E. and others (eds.) Tendencje i procesy rozwojowe współczesnych stosunków międzynarodowych [The Tendencies and Development Processes of Contemporary International Relations]. Warsaw: Scholar Publishing House, pp. 449-461.

56. STAVRIDIS, S. (2001) Why the 'Militarising' of the European Union is Strengthening the Concept of a Civilian Power Europe. EUI Working Papers, no 17.

57. TARDY, T. (2015) CSDP in action. What contribution to international security? EUISS Chaillot Papers, no. 134, May.

58. TARDY, T. (2017) The new forms of civilian crisis management. In: Tardy, T. (ed.) Recasting EU civilian crisis management. Paris: EU Institute for Security Studies, Report no. 31, January, pp. 9-22.

59. TROTT, W. (2010) An analysis of civilian, military and normative power in EU foreign Policy. POLIS Journal, vol. 4, no 1.

60. WOJNICZ, L. (2014) Wpływ procesów europeizacyjnych w Afryce na przykładzie cywilnych misji Unii Europejskiej w Demokratycznej Republice Konga [The Influence of Europeanization Processes in Africa as Exemplified by the Civilian Missions of the European Union in the Democratic Republic of Congo. The Yearbook of European Integration]. Rocznik Integracji Europejskiej, no 8, pp. 271-283.

61. ZAJĄCZKOWSKI, K. (2019) Misje cywilne i operacje wojskowe Unii Europejskiej w perspektywie wybranych teorii stosunków międzynarodowych i integracji europejskiej [EU Civilian Missions and Military Operations in the Perspective of Selected Theories of International Relations and European Integration]. Warsaw: Aspra-JR Publishing House. 
62. ZAJĄCZKOWSKI, K. (2014) O brakach i niedostatkach w polityce zagranicznej UE [On Deficiencies and Shortcomings in the Foreign Policy of the European Union]. Studia Europejskie, no 3, pp. 9-30.

63. ZIĘBA, R. (2003) Unia Europejska jako aktor stosunków międzynarodowych [The European Union as an Actor in International Relations]. Warsaw: Scholar Publishing House. 